\title{
FEEDING OF HOLOSHESTHES HETERODON EIGENMANN (TELEOSTEI, CHEIRODONTINAE) OF THE CAJURU RESERVOIR (MINAS GERAIS, BRAZIL), IN RELATION TO THE VEGETAL BIOMASS ON ITS DEPLETION ZONE
}

\author{
Márcio Camilo Carvalho Alvim ${ }^{1}$ \\ Paulina Maria Maia-Barbosa ${ }^{2}$ \\ Carlos Bernardo Mascarenhas Alves ${ }^{3}$
}

\begin{abstract}
Stomach contents of Holoshesthes heterodon Eigenmann, 1915 (Teleostei, Cheirodontinae), collected in the depletion zone of Cajuru reservoir when it was at its maximum water level in two stations with different vegetal densities, were studied in order to investigate the influence of the flooded vegetal biomass on the food quantity and quality ingested by fish. Eighteen individuals from each station were examined. The standard length was $1.53 \pm 0.05 \mathrm{~cm}$ and $1.52 \pm 0.05 \mathrm{~cm}$, respectively at the lower biomass ( $8.19 \mathrm{~kg}$ dry weight/ha) and higher biomass ( $38.10 \mathrm{~kg}$ dry weight/ha) sampling stations. The stomach repletion Index (SRI) was applied for the quantitative analysis. The alimentary index (IAi) was used for the quali-quantitative analysis, with the volume of the items obtained through the points method. SRI did not show values significatively different between the two stations, $\mathrm{p} \geq 0.05$, by applying the Mann-Whitney test. In both situations, Cladocera was the most important item. There were no correlation between the flooded vegetal biomass in the depletion zone and the intake of food by $H$. heterodon. However, as there were no empty stomachs, possibly even the lower vegetal biomass was enough to provide abundant feeding resources.

KEY WORDS. Fish feeding, reservoir, depletion zone, water level, vegetal biomass, Holoshesthes heterodon.
\end{abstract}

Reservoirs of tropical regions are young lakes and dominate fresh-water bodies in several areas (FERNANDO 1994). In Brazil, and particularly in Minas Gerais State, the high number of dams, built for electric energy generation retains a significative portion of the superficial water volume (ELETROBRÁs 1990).

The construction of hydroelectric dams and the consequent formation of artificial lakes arouses great changes in the fish community structure. The migratory species, also called piracema species, cannot transpose the barrier to complete their reproductive cycle, becoming less abundant upstream and downstream from the barrier and, in several times, absent in reservoirs (AGOSTINHO et al. 1992). In these, the ichthyofauna becomes dominated by non-migrating species, of smaller size and low longevity (AGOSTINHO et al. 1992). The changes tend to grow worse in rivers with successive dams (GoDINHO 1993).

1) Pós-graduaçăo em Ecologia e Recursos Naturais, Universidade Federal de São Carlos. Caixa Postal 676, 13565-905 São Carlos, São Paulo, Brasil.

2) Departamento de Biologia Geral, Instituto de Ciências Biológicas, Universidade Federal de Minas Gerais. Caixa Postal 486, 31270-010 Belo Horizonte, Minas Gerais, Brasil.

3) Departamento de Zoologia, Instituto de Ciências Biológicas, Universidade Federal de Minas Gerais. Caixa Postal 486, 31270-010 Belo Horizonte, Minas Gerais, Brasil. 
In reservoirs, the water level is strictly controlled according to the hydrologic cycle, periods of peak of electricity consumption and interactions with other reservoirs, making its oscillations generally regular along the year. Depending on the relief of the region, such fluctuations may flood and drain large areas, promoting the decomposition of the vegetal biomass present in the depletion zone and the carrying of substances to the water body (WETZEL 1990). In this process, the margins are exposed and flooded, the nutrients are oxidized and reduced and the community of plants has its diversity and density affected (COHEN \& RADOMSKI 1993).

The greater is the flooded vegetal biomass, the greater will be the nutrients' income, the productivity of the reservoir and the offering of food to the ichthyofauna (BERNACSEK 1984). So, the effects of the flooded terrestrial vegetation on several trophic levels should be systematically surveyed.

Studies on the feeding habits of fish in reservoirs in relation to the conditions of the depletion zone, besides supplying data about the ecology of the species, may serve as subsidies for a better comprehension of the influence of the flooded vegetal biomass, helping in the adequate management of these water bodies.

The main purpose of this study was to verify the influence of flooded vegetal biomass in the ingestion of food by Holoshesthes heterodon Eigenmann, 1915 in two different stations of the Cajuru reservoir.

\section{MATERIAL AND METHODS}

\section{Study area}

Cajuru reservoir (Fig. 1) belongs to Companhia Energética de Minas Gerais (CEMIG) (Energetic Company of Minas Gerais) and was formed in 1959 by the damming of Pará river, a right side affluent of São Francisco river. It is located at Carmo do Cajuru, Divinópolis, and Cláudio counties. Its total floodable area is of $27 \mathrm{~km}^{2}$ and the accumulated water volume is $192 \times 10^{6} \mathrm{~m}^{3}$ at its maximum quota, which occurs when the water level reaches $753,0 \mathrm{~m}$ of altitude (MELLO 1978).

\section{Species studied}

The occurrence of Holoshesthes heterodon (Fig. 2) is mentioned for the São Francisco (BRITSKI et al. 1988), Paraná (UIEDA 1984; ANDRÉ 1987) and Paraguay (SCHINDLER 1939 apud ANDRÉ 1987; BERTONI 1939 apud ANDRÉ 1987) river basins.

According to RocHE et al. (1993) $H$. heterodon is a zooplanktophagous visually oriented. They described the effects caused in the plankton community of the Lobo reservoir (SP) by its predation on microcrustaceans and Chaoborus Lichtenstein larvae. Due to its small size, $H$. heterodon is an important as a foraging item for piscivore species, such as piranhas (NORTHCOTE et al. 1986). In Cajuru reservoir littoral zone, $H$. heterodon is one of the most abundant and frequent species.

\section{Methods}

Three $70 \mathrm{~m}$ transects were demarcated parallel to the reservoir margins for the quantification of the vegetal biomass. Squares of $625 \mathrm{~cm}^{2}$ were used to determine 


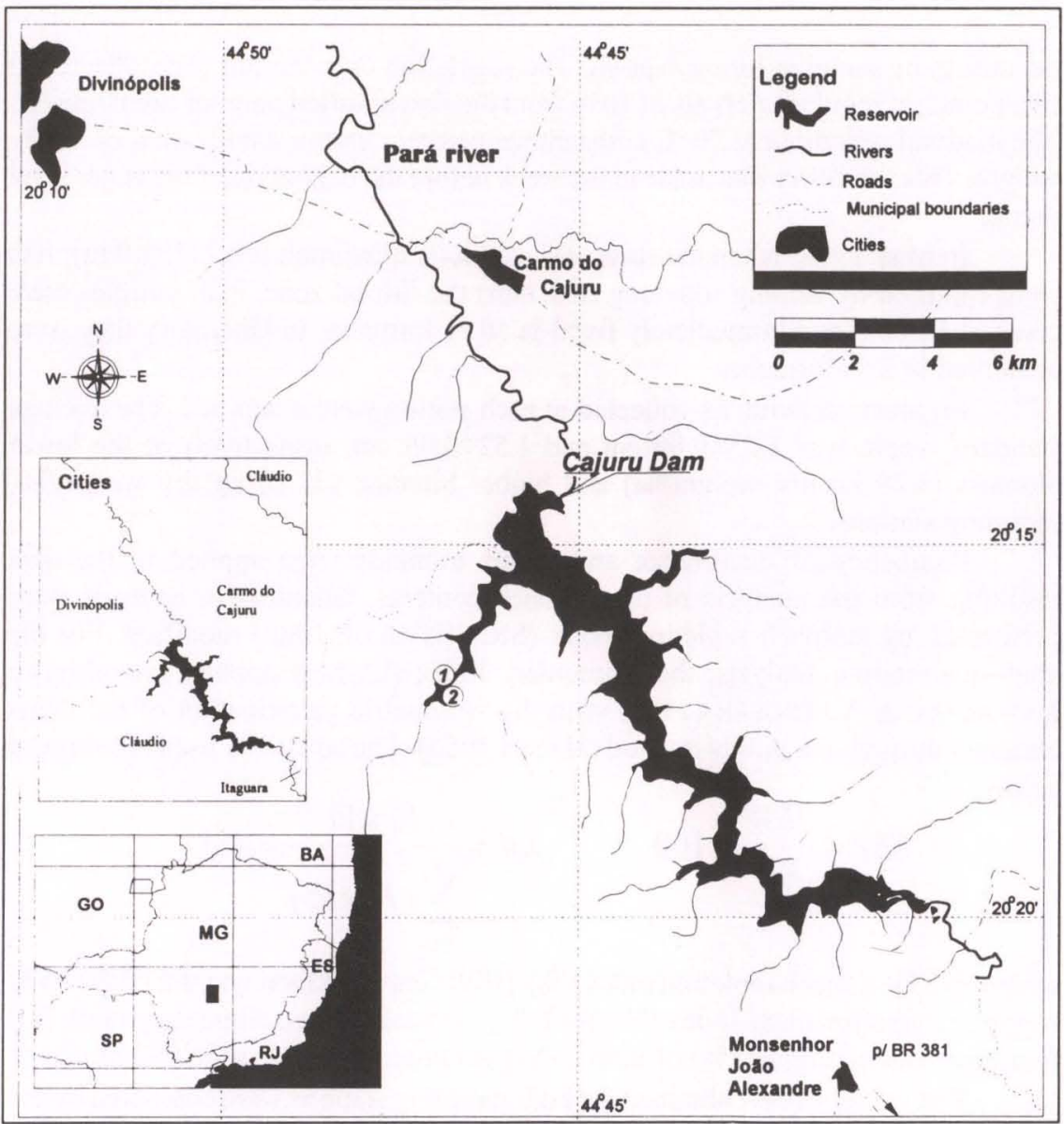

Fig. 1. Map of Cajuru reservoir, showing sampling stations.

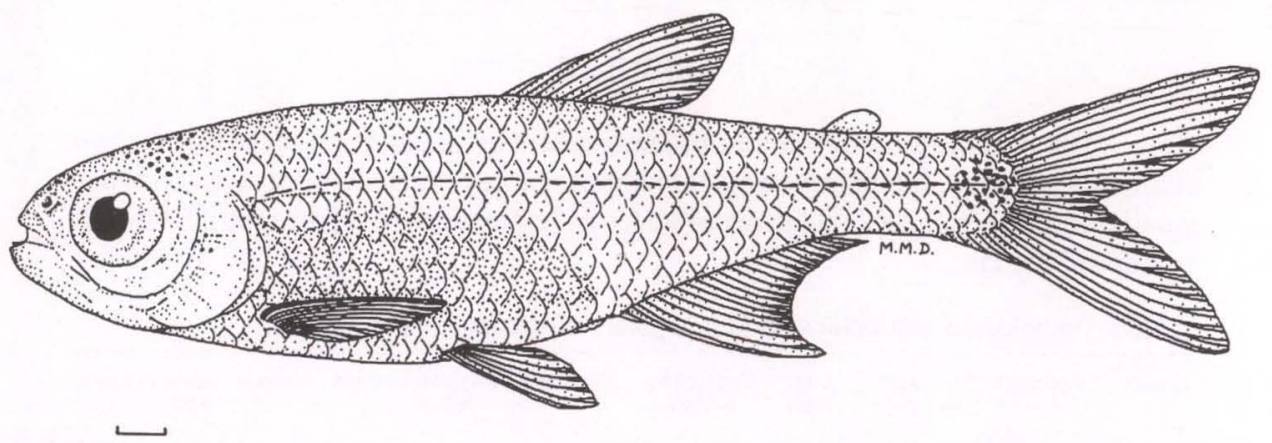

Fig. 2. Specimen of Holoshesthes heterodon (MZUSP 51474 and MCP 19927) captured in Cajuru reservoir (scale $=1 \mathrm{~mm})$. 
the area to be sampled for each point. The vegetation over the soil was collected in five points, at regular intervals of $10 \mathrm{~m}$ from the first assorted point of each transect. The material was dried at $70^{\circ} \mathrm{C}$ constant temperature up the stabilization of its dry weight. This sampling was made in the week before the beginning of the water level rising.

In May 1993, when the reservoir was at its maximum level (753,0 m), fish were captured by seining (opening of $1 \mathrm{~mm}$ ) the littoral zone. Fish samples were taken at $16: 00 \mathrm{~h}$ and immediately fixed in $10 \%$ formalin. In laboratory they were preserved in $2 \%$ formalin.

Eighteen individuals collected at each station were examined. The average standard length was $1.53 \pm 0.05 \mathrm{~cm}$ and $1.52 \pm 0.05 \mathrm{~cm}$, respectively at the lower biomass $(8.19 \mathrm{~kg}$ dry weight/ha) and higher biomass $(38.10 \mathrm{~kg}$ dry weight $/ \mathrm{ha})$ sampling stations.

Frequency of occurrence and points methods were applied to the data resulting from the analysis of the stomach contents. Quantitative analysis were performed by stomach repletion index (SRI) (HYSLOP 1980) modified. For the quali-quantitative analysis, the Alimentary Index (IAi)was applied according to KAWAKAMI \& VAZZOLER (1980) with the volumetric participation of the items obtained through the points method (HYNES 1950). The equations used are showed below:

$$
S R I=\frac{I F W}{B W} \times 100 \quad \text { Ia }=\frac{F i \times V i}{\sum_{i=1}^{n}(F i \times V i)} \times 100
$$

where: (SRI) stomach repletion index (\%); (IFW) ingested food weight; (BW) body weight; (IAi) alimentary Index (\%); (i) 1, 2, ...; (n) determined alimentary item; (Fi) frequency of occurrence (\%) of item i; (Vi) volumetric participation (\%) of item i.

The values of SRI obtained for both sampling stations were compared by the Mann-Whitney non parametric test (ZAR 1996). Besides vegetal biomass, the following limnological features were taken in each sampling station: temperature, transparency, dissolved oxygen, conductivity and $\mathrm{pH}$.

\section{RESULTS}

The limnological conditions did not present great variations between the two stations. However, the relative vegetal biomass of sampling station 1 was 4.6 times smaller than the station 2 and in absolute terms (estimated for all the area), 5.8 times smaller (Tab. I).

Table I. Limnological characteristics and vegetal biomass of sampling stations.

\begin{tabular}{ccccccccc}
\hline Station & \multicolumn{2}{c}{ Temperature $\left({ }^{\circ} \mathrm{C}\right)$} & $\begin{array}{c}\text { Secchi } \\
(\mathrm{m})\end{array}$ & $\begin{array}{c}\text { D.O. } \\
(\mathrm{mg} / \mathrm{l})\end{array}$ & $\begin{array}{c}\text { Conductivity } \\
(\mu \mathrm{S} / \mathrm{cm})\end{array}$ & $\mathrm{pH}$ & $\begin{array}{c}\text { Relative vegetal biomass } \\
(\mathrm{Kg} / \mathrm{ha})\end{array}$ & $\begin{array}{c}\text { Absolute vegetal biomass } \\
(\mathrm{Kg})\end{array}$ \\
\hline 1 & Air & Water & & & & & & \\
\hline 2 & 21.2 & 22.5 & 1.7 & 8.4 & 25.5 & 7.50 & 8.19 & 120.41 \\
\hline
\end{tabular}


The SRI values were not significatively different between station 1 $(\mathrm{X}=1.57 \pm 0.95 ; \mathrm{C} . \mathrm{V} .=60.23 \%)$ and $2(\mathrm{X}=1.46 \pm 0.86 ; \mathrm{C} . \mathrm{V} .=59.03 \%), \mathrm{p}>0.05 . \mathrm{Cla}-$ docera and insect larvae were the most frequent alimentary items (Fig. 3). In volume, Cladocera was the item with the greatest participation for both situations, followed by insects in station 1 and insect larvae in station 2 (Fig. 3). According to the IAi, Cladocera was clearly the most important item in both situations, followed by insect larvae (Fig. 4).

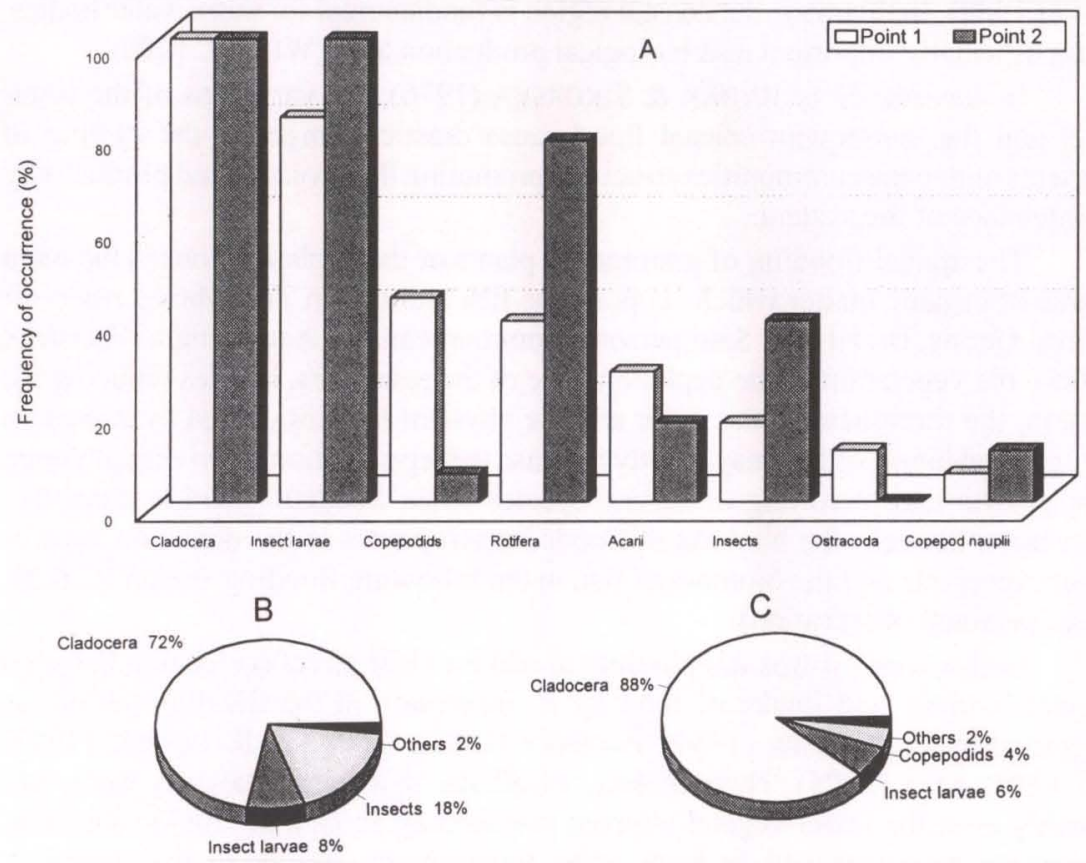

Fig. 3. Frequency of occurrence (A) and volumetric participation of preys in the stomach contents of $H$. heterodon at the lower $(B)$ and higher $(C)$ vegetal biomass stations.
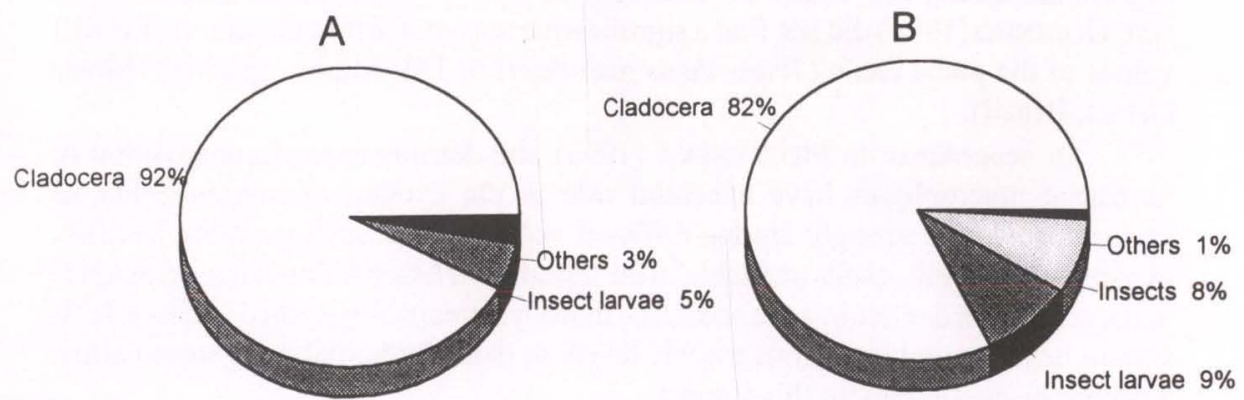

Fig. 4. Relative importance of preys in the stomach contents of $H$. heterodon at the lower (A) and higher $(\mathrm{B})$ vegetal biomass stations, according to the IAi. 


\section{DISCUSSION}

In reservoirs, a great part of the organic matter comes from the littoral zone. In these environments, the zooplankton supplemented by organisms of the mesofauna and microfauna, especially insects, is much more diverse than that of the pelagic zone, constituting an important alimentary component for fish (FERNANDO 1994). Consequently, several species procreate in the coastal zone, probably by the greatest availability of food and refuge (BEAM 1983; PLOSKEY 1985; ROZAS \& ODUM 1988). In this way, the coastal region is fundamental for these water bodies, being especially important as a biological production area (WETZEL 1990).

In accordance to RYBAK \& SIKORSKA (1976), the variations of the water level and the consequent coastal flood cause drastic changes in the cycling of nutrients and in the communities structure, promoting the diversity and productivity maintenance of the system.

The annual flooding of gramineous plants of the depletion zone is the main source of organic matter which supports the fish biomass in Três Marias reservoir (Minas Gerais, Brazil) (Y. Sato personal communication). According to PLOSKEY (1985), the vegetation of the depletion zone of the reservoirs, besides reducing the erosion, the turbidness of the water and the physical injuries caused by waves on the eggs and larvae of fish may greatly increase the reproduction, surviving of young fish, growth and recruiting of several species when flooded. There is a positive correlation between the biomass of flooded macrophytes in the depletion zone of Cajuru reservoir and the biomass of fish in the following flooding season (C.B.M. Alves personal observation).

In this work, it was not possible to make a clear direct correlation between vegetal biomass and intake of food by $H$. heterodon in the flooding period, as suggested by BERNACSEK (1984), PLOSKEY (1985), COHEN \& RADOMSKI (1993) and FERNANDO (1994). Nevertheless, as all the stomachs analyzed were full, possibly even the lower vegetal biomass was already enough to provide abundant alimentary resources and to keep water transparency similar to the station 2, allowing the visually guided search for food. The animal biomass and the flooded vegetal necromass (not considered) may have been important sources of organic matter, increasing the littoral productivity, as well as the nutrients present in the soil. GODINHO (1994) did not find a significative seasonal difference among the SRI values of the piaba facão (Triportheus guentheri) in Três Marias reservoir (Minas Gerais, Brazil).

In accordance to PIECZYNSKA (1993), the detritus from decomposition of terrestrial macrophytes have a central role in the cycling of nutrients, but its importance varies strongly among different water bodies. Such variation justifies, in part, the different results available in the literature. Thus, the flood of macrophytes in the reservoirs depletion zone should be more systematically studied and its effects should be measured in various trophic levels so that a better database would allow a deeper discussion about this subject.

In this study, Cladocera was the most important alimentary item in the two stations. ALVIM et al. (1997) showed the intense predation of $H$. heterodon over 
Cladocera attributing to the water transparency, size and shape of the body and the locomotion mechanism of the prey, as the species surveyed behaves as a visually guided predator (ROCHE et al. 1993).

They also evidence the necessity of more detailed studies on the importance of the vegetation of the depletion zone for the maintenance of the fish productivity in reservoirs.

ACKNOWLEDGMENTS. We acknowledge the Companhia Energética de Minas Gerais (CEMIG) for the logistic support for the collections and the Post-graduate Program in Ecology and Natural Resources of the Federal University of São Carlos (UFSCar) for financing the translation of this article into English. We also thank Luiz Roberto Malabarba (Museu de Ciências da PUCRS) for the species identification, and the two anonymous referees for the useful suggestions made on the manuscript.

\section{REFERENCES}

AgostinHo, A.A.; H.F. JÚlio JR. \& J.R. BORGHETTI. 1992. Considerações sobre os impactos dos represamentos na ictiofauna e medidas para sua atenuação. Um estudo de caso: reservatório de Itaipu. Unimar 14 (Supl.): 89-107.

AlviM, M.C.C.; P.M. MaiA-Barbosa \& C.B.M. Alves. 1997. Alimentação de Holoshesthes heterodon (Teleostei: Cheirodontinae) do reservatório da Usina Hidrelétrica Cajuru - MG, em relação ao nível da água. Acta Limnologica Brasiliensia 9: 45-54.

ANDRÉ, U.J. 1987. Les Cheirodontinae (Characidae, Ostariophysi) du Paraguay. Rev. Suisse Zool. 94 (1): 129-175.

BEAM, H.J. 1983. The effect of annual water level management on population trends of white crappie in Elk City Reservoir, Kansas. North. Amer. Jour. Fish. Management 3: 34-40.

BERNACSEK, G.M. 1984. Guidelines for dam design and operation to optimize fish production in impounded river basins (based on a review of the ecological effects of large dams in Africa). Cifa Tech. Pap. 11: V+98p.

BRITSKI, H.A.; Y. SATO \& A.B.S. RosA. 1988. Manual de identificação de peixes da região de Três Marias. Brasília, Codevasf, $3^{\mathrm{a}}$ ed., 115p.

COHEN, Y. \& P. RADOMSKI. 1993. Water level regulations and fisheries in Rainy Lake and the Namakan Reservoir. Can. J. Aquat. Sci. 50: 1934-1945.

ELETROBRÁs. 1990. Programas para o desenvolvimento técnico e institucional do setor elétrico em meio ambiente. In: Plano diretor de meio ambiente do setor elétrico 1991/1993 (Resumo executivo). Rio de Janeiro, Eletrobrás, 72p.

FERNANDO, C.H. 1994. Zooplankton, fish and fisheries in tropical freshwaters. Hydrobiologia 272: 105-123.

GodinHO, A.L. 1993. E os peixes de Minas em 2010? Ciência Hoje 16 (91): 44-49.
. 1994. Biologia reprodutiva da piaba-facão, Triportheus guentheri (Characiformes, Characidae) e o manejo hidrológico da represa de Três Marias. Rev. Brasil. Biol. 54 (3): 515-524.

HYNES, H.B.N. 1950. The food of freshwater sticklebacks (Gasterosteus aculeatus and Rygosteus pungituis) with a review of methods used in studies of foods of 
fishes. Jour. Animal Ecol. 19: 36-58.

HysLoP, E.J. 1980. Stomach contents analysis - a review of methods and their application. Jour. Fish Biol. 17: 411-429.

KAWAKAMI, E. \& G. VAZzolER. 1980. Método gráfico e estimativa de índice alimentar aplicado no estudo de alimentação de peixes. Bolm. Inst. Oceanogr., São Paulo, 29 (2): 205-207.

MELlo, F.M. 1978. Grandes barragens do Brasil. Construção Pesada, São Paulo, 95: $16-230$.

NorTHCOTE, T.G.; R.G. NorThCOTE \& M.S. ARCIFA. 1986. Differential cropping of the caudal fin lobes of prey fishes by the piranha, Serrasalmus spilopleura Kner. Hydrobiologia 141: 199- 205.

PIECZYNSKA, E. 1993. Detritus and nutrient dynamics in the shore zone of lakes: a review. Hydrobiologia 251: 49-58.

PLOSKEY, G.R. 1985. Impacts of terrestrial vegetation and preimpoundment clearing on reservoir ecology and fisheries in the USA and Canada. FAO Fish. Tech. Pap. 258: V+1-35.

Roche, K.F.; E.V. SAmPaio; D. Teixeira; T. Matsumura-Tundisi; J.G. Tundisi \& H.J. DumONT. 1993. Impact of Holoshesthes heterodon Eigenmann (Pisces: Characidae) on the plankton community of a subtropical reservoir: the importance of predation by Chaoborus larvae. Hydrobiologia 254: 7-20.

ROZAS, L.P. \& W.E. ODUM. 1988. Occupation of submerged aquatic vegetation by fishes: testing the roles of food and refuge. Oecologia 77: 101-106.

RYBAK, J.I. \& V. SIKORSKA. 1976. Environment, p.7-26. In: E. PIECZYNSKA (Ed.)

Selected problems of lake littoral ecology. Warszawa, Wydawnictwa Uniwersytetu Warszawskiego, 237p.

UIEDA, V.S. 1984. Ocorrência e distribuição dos peixes em um riacho de água doce.

Rev. Brasil. Biol. 44 (2): 203-213.

WETZEL, R.G. 1990. Land-water interfaces: Metabolic and limnological regulators.

Verh. int. Ver. Limnol. 24: 6-24.

ZAR, J.H. 1996. Biostatistical analysis. New Jersey, Prentice Hall, $3^{\text {rd }}$ ed., X+662p.

Recebido em 19.IX.1997; aceito em 19.XI.1998 